\title{
THE PUBLIC SERVICES POLICY TO CUSTOMER SATISFACTION AT INTERNATIONAL AIRPORT BEFORE AND MOMENT COVID-19
}

\author{
SUNARNO $^{1}$, SOESILO ZAUHAR ${ }^{2}$, MARDIYONO ${ }^{3} \&$ SURYADI $^{4}$ \\ ${ }^{1}$ Indonesian Aviation Polytechnic (IAP) Curug \\ ${ }^{2,3,4}$ Promotor and Co-Promotor, Doctor Program of Public Administration, Faculty of Administrative Sciences University \\ Brawijaya Malang, Indonesia
}

\section{ABSTRACT}

This research uses a descriptive type, and this research was conducted in two different conditions and situations "September - November 2019 or before covid-19 and March - April 2020 or moment covid-19". So that there are two unique data and analysis results presented in this study that can be read on the description of the next article. SoekarnoHatta International Airport has won the highest "Diamond Award" in the aspect of Service Quality Award in 2018. This study aims to measure the strength of: "company image, service quality and customer satisfaction, and this type of research is descriptive research". Research which describes the relationship between the phenomena being investigated without going through hypothesis testing.

The results of this study prove that "service quality is an important aspect that is used as a measure for customer satisfaction which is then followed by company image. A service is considered satisfactory if the service can meet customer needs and expectations". Basically, customer satisfaction and dissatisfaction with a product or service will affect the next consumer behaviour pattern after the purchase process occurs.

Customers who experience high satisfaction will tend to stay with the current product or service provider. "If customer satisfaction has been met, it is beneficial for a company, private institution or government. So that it can be drawn a common thread that service quality is the key to success in various service businesses". This study is interesting that for airport services (before and moment covid-19) the most important thing is the guarantee and safe service from the service provider.

KEYWORDS: Customer Satisfaction, International Airport, Corporate Image, Service Quality, Covid-19

Received: Oct 05, 2020; Accepted: Oct 25, 2020; Published: Dec 08, 2020; Paper Id.: IJBMROCT20206

\section{A. INTRODUCTION}

The need for transportation services is qualitative and has different points. Over the last ten years or so; "airplanes have been transformed into a means of public transportation (commercial) that have undergone a phenomenal transformation. Services at Soekarno - Hatta Airport received awards from various parties, including; Service Quality Award, World Airport Awards, Best Airport, The World's Most Improved Airport by Skytrax and others".

Soekarno-Hatta International Airport, Tangerang which is managed by PT Angkasa Pura II (Persero) has won the highest award (Diamond Award) in the aspect of Service Quality Award (SQA) in 2018. The award was held at Hotel Mulia, Senayan, South Jakarta. This award is obtained based on customer perceptions compiled by the Carre Service Quality Monitoring (CSQM) research institute. 
The CSQM Award 2018 is an award event held based on national research on customer satisfaction with the Service Quality Index (SQI). "Soekarno-Hatta Airport is not only considered to have the best quality in providing services. But also extraordinary and totality to meet the needs of customers, especially in digital services". Figure 1; "the development of air transportation users in 2013-2019 at Soekarno Hatta Airport is as shown in the following figure (Angkasa Pura II, 2020).

Based on the picture above, it can be seen that the condition of arrivals in aviation transportation in Indonesia; "in 2013 reached a high enough number and a surge in passengers occurred in 2014. However, from 2015 to 2019 there was a decrease in the number of passengers arriving. For departures from 2013 to 2015 it is still considered normal, while from 2015 to 2018 there was a surge in passenger arrivals, and in 2019 there was a decrease in the number of departing passengers".

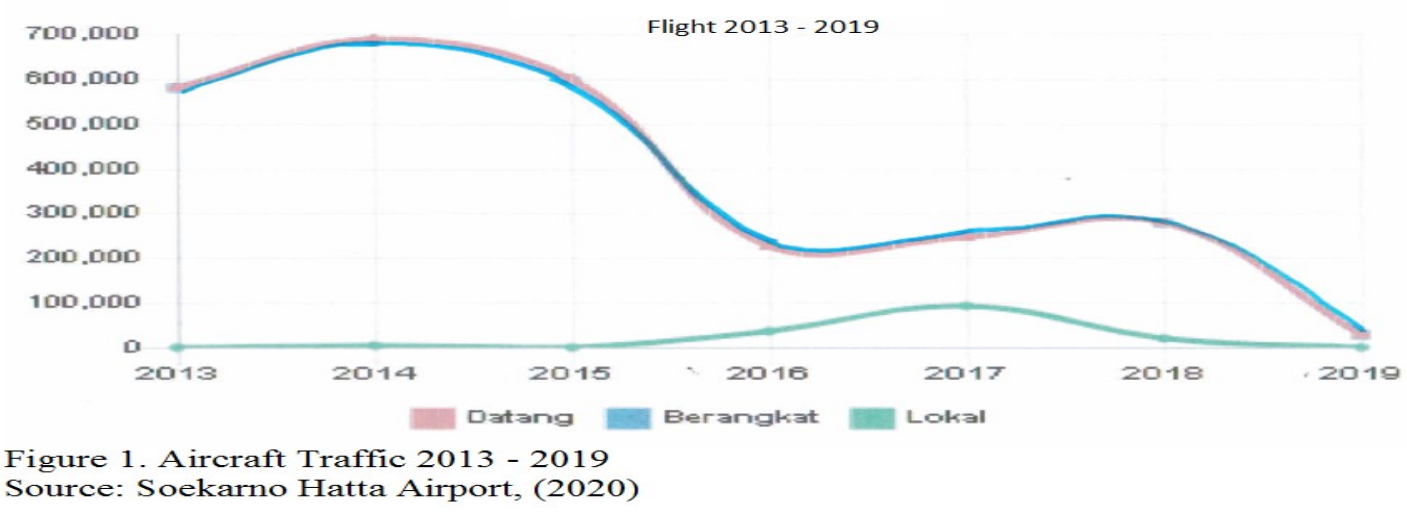

\section{B. LITERATURE REVIEW}

Zauhar (2009) "has at least two dimensions to see the meaning of closeness between public service organizations and the community, namely normative closeness, meaning the extent to which policies or rules are made that voice the desires. Interests of the community, and closeness in an area, which means that for this closeness it is necessary to have organizational units that can be easily reached by the community". By area, public services can be carried out by organizational units that are close to the community so that the organization is agile, responsive, and understands precisely the needs of local communities which in turn can increase the effectiveness of public services (Effendi, 2005). Public services that are faster, cheaper, and better, the existing service standards are often unable to maintain their existence. On the other hand, in the field of public services, extra costs or illegal fees are a common picture seen in community offices. This is because the paradigm of government has not undergone a fundamental change (Suwondo, 2011).

Arief (2014), “in general public services are identical to the representation of the existence of government bureaucracy, because they are directly related to one of the functions of the government, namely providing services. Therefore, a quality of public service is a reflection of a quality of government bureaucracy. In the past, the public service paradigm gave a very big role to the government as the sole provider". The role of parties outside the government has never been placed or marginalized. The public and the private sector have only a minor role in the delivery of public services. With regard to reforms in the public sector (Lupiyoadi, 2014). One of the important principles that change the paradigm of public services is the principle of steering rather than rowing. With regard to this principle, the government is expected to act more as a guide than just a paddle. The pedalling function can be performed more efficiently by other 
professionals (Zauhar, 2009). This principle explains that the government cannot continuously work alone, and must begin to change the paradigm of services so that the objectives of service delivery can be better achieved.

According to the Tjiptono (2010), "states that services are activities, benefits or satisfaction offered for sale or services are activities that can be individually identified which are essentially intangibles, which fulfil needs and do not have to be bound. In the sale of other products or services, tangibles may or may not be necessary to produce services". However, even though the use of the object is necessary, there is no transfer of title to the object or permanent ownership (Arief, 2014).

Islamy (2001), "argues that service is a process of meeting needs through direct activities of others. The definition of public service, according to Effendi (2005) is the provision of services needed by people or communities who have an interest in the organization in accordance with the basic rules and procedures that have been determined". Djumara (2011), "states that what is meant by service from the government side is the process of activities to meet the needs of others, either rights or obligations due to government regulations, and the form can be in the form of services or services". Then Islamy (2001), "community service is a helpful, friendly and professional attitude that satisfies society and causes people to come back to ask for service again".

Suwondo (2011), "states that the meaning of public service (public service) always related to the meaning of public, especially in relation to public administration studies. Public administration is no longer traditionally defined as merely institutional (for example; the state), but in relation to how much influence or relation these institutions have with the public interest".

According to Arief (2014), "the pressure of public understanding is more directed at users of services performed by a public servant, in this case a government employee. The most concrete users of public services, of course, are those who directly receive or enjoy these public services". Even so, the conceptuality of the parties referred to as users of public services. According to the thought of Effendi (2005), "based on the understanding that has been described above, it can be taken a meaning that public service is an effort made by parties that provide services (private or government) to meet public needs in accordance with laws and regulations that have been established as operational standards in providing services". Services there are activities carried out either directly interacting with the people being served or assisted by equipment to provide satisfaction (Islamy, 2001).

Armistead (2005), "a public service commodity is a public service, namely a service which, considering its nature involves many people, its management, production and sale are placed under government control. Listening to the statements above, it can be said that it is the government's duty to be able to provide satisfaction in providing services to the public". This is expected to provide quality services according to public expectations. Kasali (2010), "image is an impression that arises because of an understanding of a reality. The understanding itself emerges from various sources, one of which is through public opinion, namely the opinion of a group of people in the public segment. Everyone can have a different image of the same object”. According to Robert (2011), several aspects contained in the company's image are;

- Reputation, "assessment of various aspects of the company both past and present at Soekarno-Hatta International Airport".

- Credibility "is a condition or condition that can be trusted and can be accounted for as it should be at SoekarnoHatta International Airport”. 
- Electability “is someone's interest in choosing something Soekarno-Hatta International Airport”.

- Popularity "is the level of recognition of an object (goods, services, a figure, and institutions) in the eyes of society Soekarno-Hatta International Airport”.

- Acceptability "means acceptability, appropriateness and appropriateness. This word comes from borrowing the word acceptability".

Kotler (2014), "states that service quality is a level of service related to meeting the expectations and needs of customers or users. This means that service is said to be of quality if a certain company or institution is able to provide products and services (services) in accordance with the wishes, needs and expectations of customers or users”. According to Parasuraman \& Berry (2005), dimensions regarding service quality issues; "1). Reliability is the ability to provide the promised service immediately, accurately and satisfactorily; 2). Responsiveness is the desire of staff to help customers provide services responsively; 3). Assurance is the knowledge and courtesy of the company's staff and the ability to foster a sense of assurance; 4). Attention "is ease of good communication the needs of customers, and 5). Tangible, "is a form of service that can be seen directly, including physical facilities, personnel equipment and means of communication".

Kotler \& Kevin (2016), "state that customer satisfaction is more about feeling happy or disappointed from someone who appears after comparing products and services from what they think with what they expect”. According Alma (2013) at least the customer satisfaction includes aspects: “1). Products, everything that can be offered to a market to fulfil a want or need; 2). Costs, the amount of money needed to obtain any combination of products and services; 3 ). Services, service activities provided by the company with fast and precise time, and 4). Facilities, infrastructure provided by the company to support the sale of goods or services".

Kotler (2014), “satisfaction as a person's feelings of pleasure or disappointment resulting from comparing a product's perceived performance (or outcome) in relation to his or her expectations". According to Hansemark and Albinsson (2004), "satisfaction is an overall customer attitude towards a service provider, or an emotional reaction to the difference between what customers anticipate and what they receive, regarding the fulfilment of some need, goal or desire”. Cravens \& Nigel (2004) "said that satisfaction can be associated with feelings of acceptance, happiness, relief, excitement, and delight. There are many factors that affect customer satisfaction". According to Zinkhan \& Donny (2017), "these factors include friendly employees, courteous employees, knowledgeable employees, helpful employees, accuracy of billing, billing timeliness, competitive pricing, service quality, good value, billing clarity and quick service". This is shown in (figure 2) 


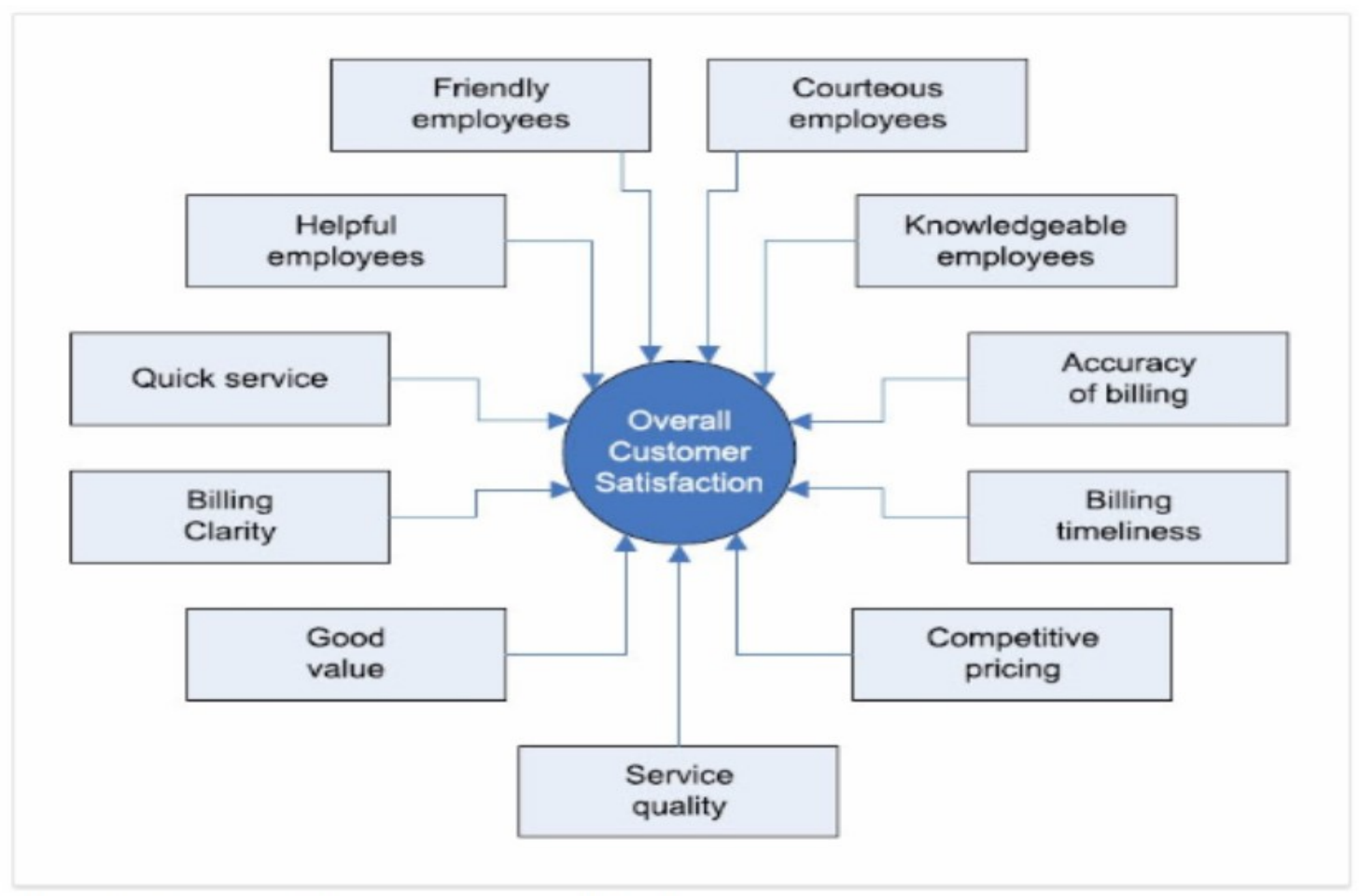

Figure 2. Factors affect customer satisfaction.

Source: Kotler (2014)

Armstrong \& Kotler (2015), "customer satisfaction is a kind of measure of how products or services provided by a company meet customer expectations. Customer satisfaction is one of the most important indicators of consumer purchase intentions and loyalty". High-standard customer service can win your clients' hearts and make you recognizable within your target group. Nowadays when social media play such an important role in making decisions it's crucial to keep an eye on the quality of customer service you provide (Basu Swasta, 2011). If don't care about customers' satisfaction, don't expect them to care about your services or products.

\section{RESEARCH METHOD}

The type of research used is descriptive research, according to Arikunto (2015), "descriptive research is a study that describes the relationship between the phenomena being investigated without going through hypothesis testing. Primary data collection uses a questionnaire or a list of questions". Then the data analysis of this study uses the "Spearman Rank Correlation". As follows;

$$
r=\frac{N(\Sigma X Y)-(\Sigma X \Sigma Y)}{\sqrt{\left[N \Sigma X^{2}-(\Sigma X)^{2}\right]} \sqrt{\left[N \Sigma Y^{2}-(\Sigma Y)^{2}\right]}}
$$

Information:

$r=$ correlation coefficient

$\mathrm{x}=$ score of each item

$\mathrm{Y}=$ total variable score

$\mathrm{N}=$ number of samples (Creswell, 2015). 
The analysis was assisted by a computer software program, "namely the SPSS 20 for Windows application (Statistical Program for Social Science), with a 95\% confidence level or a 5\% chance of error”.

\section{RESULTS AND DISCUSSIONS}

Respondents in this study were 100 people, "visitors and passengers of Soekarno Hatta Airport, Cengkareng, who were selected or determined by simple random sampling or simple random sampling". With the following descriptions (see table 1).

Based on table 1; "it can be seen that most of the respondents in this study were men, amounting to 61 people, with 48 people from higher education (S1, S2, S3), and the frequency to airport between 5 - 10 times with a total of 55 person. This respondent's description has been considered very supportive for research purposes”.

Table 1

Respondents description (before covid-19)

\begin{tabular}{|c|c|c|c|}
\hline No & Deskripsi Responden & Frequency & Percent \\
\hline \multicolumn{4}{|c|}{ Gender } \\
\hline 1 & Male & 61 & $46 \%$ \\
\hline 2 & Famale & 39 & $54 \%$ \\
\hline & Amount & 100 & $100 \%$ \\
\hline \multicolumn{4}{|c|}{ Education } \\
\hline 1 & SD / equivalent & 6 & $6 \%$ \\
\hline 2 & SMP / equivalent & 14 & $14 \%$ \\
\hline 3 & SMA / equivalent & 32 & $32 \%$ \\
\hline 4 & Higher Education (S1, S2, S3) & 48 & $48 \%$ \\
\hline & Amount & 100 & 100 \\
\hline \multicolumn{4}{|c|}{ Frequency to Airport } \\
\hline 1 & It's the first time & 11 & $11 \%$ \\
\hline 2 & Between $2-5$ times & 21 & $21 \%$ \\
\hline 3 & Between $5-10$ times & 55 & $55 \%$ \\
\hline 4 & More than 10 times & 13 & $13 \%$ \\
\hline & Amount & 100 & 100 \\
\hline
\end{tabular}

Source: Primary data processed, 2020

Based on table 2; "it can be seen that for corporate image most of the respondents in this study viewed, Credibility (X1.2) for Company Image with a total of 35\%, then for service quality was Guarantee (X2.4) with a total of $34 \%$ and for Customer Satisfaction. (Y) is the Facility (Y1.4) with a total of $32 \%$ and also Service (Y1.3) which is $29 \%$ for the aspect of Customer Satisfaction". 
Table 2

Respondent rating description (before covid-19)

\begin{tabular}{|c|c|c|c|c|}
\hline No & Variabel & Indicator & Frequency & Percent \\
\hline \multirow{5}{*}{1} & \multirow{5}{*}{ Corporate Image $\left(\mathrm{X}_{1}\right)$} & Reputation $\left(\mathrm{X}_{1.1}\right)$ & 17 & $17 \%$ \\
\hline & & Credibility $\left(\mathrm{X}_{1.2}\right)$ & 35 & $35 \%$ \\
\hline & & Elektability $\left(\mathrm{X}_{1.3}\right)$ & 17 & $17 \%$ \\
\hline & & Popularity $\left(\mathrm{X}_{1.4}\right)$ & 15 & $15 \%$ \\
\hline & & Acceptability $\left(\mathrm{X}_{1.5}\right)$ & 16 & $16 \%$ \\
\hline & & & 100 & $100 \%$ \\
\hline \multirow{5}{*}{2} & \multirow{5}{*}{ Service Quality $\left(\mathrm{X}_{2}\right)$} & Physical evidence $\left(\mathrm{X}_{2.1}\right)$ & 20 & $20 \%$ \\
\hline & & Reliability $\left(\mathrm{X}_{2.2}\right)$ & 17 & $17 \%$ \\
\hline & & Responsiveness $\left(\mathrm{X}_{2.3}\right)$ & 15 & $15 \%$ \\
\hline & & Guarantee $\left(\mathrm{X}_{2.4}\right)$ & 34 & $34 \%$ \\
\hline & & Empathy $\left(\mathrm{X}_{2.5}\right)$ & 14 & $14 \%$ \\
\hline & & & 100 & $100 \%$ \\
\hline \multirow[t]{4}{*}{3} & \multirow{4}{*}{$\begin{array}{l}\text { Customer Satisfaction } \\
\text { (Y) }\end{array}$} & Product $\left(\mathrm{Y}_{1.1}\right)$ & 16 & $16 \%$ \\
\hline & & Cost $\left(\mathrm{Y}_{1.2}\right)$ & 23 & $23 \%$ \\
\hline & & Service $\left(\mathrm{Y}_{1.3}\right)$ & 29 & $29 \%$ \\
\hline & & Facility $\left(\mathrm{Y}_{1.4}\right)$ & 32 & $32 \%$ \\
\hline & & & 100 & $100 \%$ \\
\hline
\end{tabular}

Source: Primary data processed, 2020

Based on table 3; "it can be seen that there is a significant relationship between Company Image (X1) and Customer Satisfaction (Y) of $0.678(67.8 \%)$ and there is a relationship between Service Quality (X2) and Customer Satisfaction $(\mathrm{Y})$ of $0.725(72,5 \%)$. So that service quality becomes an important aspect that is used as a measure for customer satisfaction and is followed by the company's image".

Table 3

Correlation variabel research (before covid-19)

Nonparametric Correlations

Correlations

\begin{tabular}{|c|c|c|c|c|}
\hline & & & $\times 1$ & $\mathrm{Y}$ \\
\hline \multirow[t]{2}{*}{ Spearman's rho } & $\times 1$ & $\begin{array}{l}\text { Correlation Coefricient } \\
\text { Sig. (2-tailed) } \\
\mathrm{N}\end{array}$ & $\begin{array}{c}1.000 \\
100\end{array}$ & $\begin{array}{l}.678^{* 1} \\
.000 \\
100\end{array}$ \\
\hline & $\mathbf{Y}$ & $\begin{array}{l}\text { Correlation Coefficient } \\
\text { Sig. (2-tailed) } \\
\mathrm{N}\end{array}$ & $\begin{array}{r}.678^{*} \\
.000 \\
100\end{array}$ & $\begin{array}{c}1.000 \\
100\end{array}$ \\
\hline
\end{tabular}

Correlation is significant at the 0.05 level (2-tailed).

Customer satisfaction can only be formed if the customer is satisfied with the service received by the service provider. So that; "customer satisfaction is the basis for the realization of loyal or loyal customers. Customer satisfaction or dissatisfaction is a customer response to the perceived mismatch between previous expectations and perceived actual performance". Even customer satisfaction is an emotional response to an evaluation of the consumption experience of a product or service. Furthermore, customer satisfaction is an after-purchase evaluation where the alternatives chosen are at least equal to or exceeding customer expectations (Azize, 2011).

Based on table 4; "it can be seen that most of the respondents in this study were men, amounting to 56 people, with 41 people from higher education (S1, S2, S3), and the frequency to airport between 5 - 10 times with a total of 51 
person". This respondent's description has been considered very supportive for research purposes.

Table 4

Respondents description (moment covid-19)

\begin{tabular}{|c|c|c|c|}
\hline No & Deskripsi Responden & Frekunci & Percent \\
\hline \multicolumn{4}{|c|}{ Gender } \\
\hline 1 & Male & 56 & $56 \%$ \\
\hline 2 & Famale & 44 & $44 \%$ \\
\hline & Amount & 100 & $100 \%$ \\
\hline \multicolumn{4}{|c|}{ Education } \\
\hline 1 & SD / equivalent & 7 & $7 \%$ \\
\hline 2 & SMP / equivalent & 16 & $16 \%$ \\
\hline 3 & SMA / equivalent & 36 & $36 \%$ \\
\hline 4 & Higher education (S1, S2, S3) & 41 & $41 \%$ \\
\hline & Jumlah & 100 & $100 \%$ \\
\hline \multicolumn{4}{|c|}{ Frequency to Airport } \\
\hline 1 & It's the first time & 14 & $14 \%$ \\
\hline 2 & Between $2-5$ & 24 & $24 \%$ \\
\hline 3 & Between $5-10$ & 51 & $51 \%$ \\
\hline 4 & More than 10 & 11 & $11 \%$ \\
\hline & Jumlah & 100 & $100 \%$ \\
\hline
\end{tabular}

Source: Primary data processed, 2020

Based on table 5; "it can be seen that for corporate image most of the respondents in this study viewed, Credibility (X1.2) for Company Image with a total of 39\%, then for service quality was Guarantee (X2.4) with a total of 37\% and for Customer Satisfaction. (Y) is the Facility (Y1.3) with a total of $41 \%$ and also Service (Y1.4) which is $27 \%$ for the aspect of Customer Satisfaction". 
Table 5

Respondent rating description (moment covid-19)

\begin{tabular}{|c|c|c|c|c|}
\hline No & Variabel & Indicator & Frequency & Percent \\
\hline \multirow{5}{*}{1} & \multirow{5}{*}{ Corporate Image $\left(\mathrm{X}_{1}\right)$} & Reputation $\left(\mathrm{X}_{1.1}\right)$ & 18 & $18 \%$ \\
\hline & & Credibility $\left(\mathrm{X}_{1.2}\right)$ & 39 & $39 \%$ \\
\hline & & Elektability $\left(\mathrm{X}_{1.3}\right)$ & 13 & $13 \%$ \\
\hline & & Popularity $\left(\mathrm{X}_{1.4}\right)$ & 14 & $14 \%$ \\
\hline & & Acceptability $\left(\mathrm{X}_{1.5}\right)$ & 16 & $16 \%$ \\
\hline & & & 100 & $100 \%$ \\
\hline \multirow{5}{*}{2} & \multirow{5}{*}{ Service Quality $\left(\mathrm{X}_{2}\right)$} & Physical evidence $\left(\mathrm{X}_{2.1}\right)$ & 23 & $23 \%$ \\
\hline & & Reliability $\left(\mathrm{X}_{2.2}\right)$ & 14 & $14 \%$ \\
\hline & & Responsiveness $\left(\mathrm{X}_{2.3}\right)$ & 15 & $15 \%$ \\
\hline & & Guarantee $\left(\mathrm{X}_{2.4}\right)$ & 37 & $37 \%$ \\
\hline & & Empathy $\left(\mathrm{X}_{2.5}\right)$ & 11 & $11 \%$ \\
\hline & & & 100 & $100 \%$ \\
\hline \multirow[t]{4}{*}{3} & \multirow{4}{*}{$\begin{array}{l}\text { Customer Satisfaction } \\
\text { (Y) }\end{array}$} & Product $\left(\mathrm{Y}_{1.1}\right)$ & 11 & $11 \%$ \\
\hline & & Cost $\left(\mathrm{Y}_{1.2}\right)$ & 21 & $21 \%$ \\
\hline & & Service $\left(\mathrm{Y}_{1.3}\right)$ & 41 & $41 \%$ \\
\hline & & Facility $\left(\mathrm{Y}_{1.4}\right)$ & 27 & $27 \%$ \\
\hline & & & 100 & $100 \%$ \\
\hline
\end{tabular}

Source: Primary data processed, 2020

Based on table 6; "it can be seen that there is a significant relationship between Company Image (X1) and Customer Satisfaction (Y) of $0.680(68 \%)$ and there is a relationship between Service Quality (X2) and Customer Satisfaction (Y) of $0.751(75,1 \%)$. So that service quality becomes an important aspect that is used as a measure for customer satisfaction and is followed by the company's image".

Table 6

Correlation variable ( moment covid-19)

Correlations

\begin{tabular}{|lll|r|r|}
\hline & & $X 2$ & \multicolumn{1}{c|}{$Y$} \\
\hline Spearman's rho & $X 2$ & Correlation Coefficient & 1.000 & $.725^{* * *}$ \\
& & Sig. (2-tailed) & .000 \\
& $\mathrm{~N}$ & 100 & 100 \\
\cline { 2 - 5 } & $\mathrm{Y} \quad$ Correlation Coefficient & $.725^{* *}$ & 1.000 \\
& Sig. (2-tailed) & .000 &. \\
& & $\mathrm{~N}$ & 100 & 100 \\
\hline
\end{tabular}

Correlation is significant at the 0.05 level (2-tailed).

Source: Primary data processed, 2020

Customer satisfaction can only be formed if the customer is satisfied with the service received by the service provider. So that "customer satisfaction is the basis for the realization of loyal or loyal customers. Customer satisfaction or dissatisfaction is a customer response to the perceived mismatch between previous expectations and perceived actual performance". Even customer satisfaction is an emotional response to an evaluation of the consumption experience of a product or service. Furthermore, customer satisfaction is an after-purchase evaluation where the alternatives chosen are at least equal to or exceeding customer expectations (Foster, 2005). 


\section{E. CONCLUSIONS}

Service quality is an important aspect that is used as a measure for customer satisfaction which is then followed by the company's image. "Consumer satisfaction is the feeling of pleasure or disappointment of a consumer who appears after comparing the results or benefits of the product or service with the expected benefits / outcomes of the product or service". Achieving customer satisfaction is one of the main goals of every company.

Customer satisfaction will certainly be an important point for the existence of a company. Not only that "satisfying customers can also improve the quality of the company in competing with other companies. From a consumer's point of view, consumers who are satisfied with the benefits of a product or service will definitely reuse the same product or service. Thus, customer satisfaction is the main key to increasing the rate or sales volume". It is interesting that for airport services (before and moment covid-19) the most important thing is the guarantee and safe service from the service provider.

The efficiency and effectiveness of the bureaucracy can be improved by developing a professional and nonpartisan public administration. "The dominant theme of Wilson's thinking is an apparatus or bureaucracy that is neutral or separated from the hustle and bustle of political interests. Therefore state administration must be based on administrative principles and oriented towards achieving economic rational goals". State administration is the implementation or implementation of public policy, this is the area of the technical bureaucrats. Meanwhile, the formulation of policies is a political area and is the field of statesmen or politicians".

\section{REFERENCES}

1. Alma, Buchari (2013). Marketing Management and Services Marketing. Alfabeta Publisher. Bandung.

2. Angkasa Pura II (2020). National and International Flights at Several International Airports 2018 and 2019. Angkasa Pura II. Jakarta.

3. Arikunto, Suharsimi (2015). Research Procedure A Practical Approach. The publisher, Rineka Cipta. Jakarta.

4. Arief, D. Sulistya (2014). Professionalism of Government Officials in Public Services. Publisher, Diponogoro University, Press. Semarang.

5. Armstrong \& Kotler (2015). Marketing an Introducing. Prentice Hall Twelfth Edition, Pearson Education, England Inc.

6. Armistead, et al (2005). Service Recovery; a framework and empirical investigation”, Journal of Operations Management, vol. 18, no. 4, pp.

7. Aurellia, Duran (2018). Marketing and Globalization. Routledge; 1 Edition. Pearson Education. New Jersey.

8. Azize, Sahin et al. (2011). The effect of Corporate Image. Trust and Satisfaction on Building Brand Loyalty, An Empirical Research on Global Brands. Pearson Education, England. Inc.

9. Basu Swastha (2011). Marketing Management - Consumer Behavior Analysis, Publisher, BPFE. Yogyakarta.

10. Cravens, W. David and Nigel F. Piercy (2004). Strategis Marketing. International Edition. McGraw-Hill.

11. Creswell, John. W (2015). Research Design: Qualitative, Quantitative, and Mixed Methods Approaches. Third Edition. SAGE Publications India Pvt. Ltd. 
12. David R. Malpass (2019). Competition in the Banking. Ekcekutif the World Bank IBRD. Banque mondiale. French.

13. David, S. Eger (2018). Corporate Image in Contemporary Competitive Environment. New Jersey, NJ: Prentice Hall.

14. Djumara, Noorsyamsa (2011). Towards a New Format of Public Service. Publisher, State Administration Institute, Jakarta.

15. Effendi, Slamet (2005). Public Service Quality Management. State Administration Institute, Jakarta

16. Foster, B. D., \& Cadogan, J. W (2005). Relationship selling and customer loyalty: An empirical investigation. Marketing Intelligence \& Planning, 18 (4), 185-199.

17. Griffin, Ricky, W. \& Ronald J. Ebert (2007). Bisnis, edisi kedelapan jilid satu. Terjemahan. Erlangga. Jakarta.

18. Han, C. Jenkins. Smith (2017). Quantitative Research Methods: For Political Science and Administration: 3rd Edition. University of Oklahoma.

19. Hessel, B (2011). Corporate Image Has an Effect on Customer Satisfaction. Journal of Contemporary Research in Business, $4(5)$.

20. Islamy, M. Irfan (2001). Principles of State Policy Formulation, Second Edition, First Edition. Bina Aksara. Jakarta.

21. Jonathan, Sarwono (2015). Quantitative and Qualitative research methods. (Using the SPSS Procedure). Graha Media. Yogyakarta.

22. Kasali, Gustian (2010). Strategy to Build Company Image. Publisher, Alpha Beta. Bandung.

23. Kotler, Philip (2014). Marketing Management, 15th. Edition New Jersey: Pearson Pretice Hall, Inc.

24. Kotler, P. \& Kevin, L. Keller (2016). Marketing Management (12th ed.). Upper Saddle River: Pearson Prentice Hall.

25. Lupiyoadi, S (2014). Service Marketing Management. Edition 3. Publisher, Salemba Empat. Jakarta.

26. Norman H. Nie and Hadlai Hull (2008). Statistical Package For The Solution Sciences (SPSS) For Data Analysis. Stanford University of Chicago.

27. Oliver, P (2007). Customer Loyalty: Research, Theory and Practice. United Kingdom, John Wiley \& Sons Ltd.

28. Parasuraman \& Berry, L (2005). A multiple-item scale for measuring customer perception of service quality. Journal of Retailing, 64(1), 12-40

29. Prawitra, Tedy, S (2016). Citra Perusahaan dan Kepuasan Konsumen. Penerbit, Alfa Beta. Bandung.

30. Robert S. Kaplan (2011). The Effect Corporate Image As A Mediator Between Service Quality And Customer Satisfaction. Case Study Background Boston Mutual Insurance Company. Published by Harvard Business School. MA.02163. Vol. 34 No 7, pp. 97-125.

31. Soemirat and Ardianto (2009). Company Image and Customer Loyalty. Journal of Marketing Management, 4 (1), $172-182$.

32. Sugiyono (2015). Combination Research Methods (Mix Methods). The publisher, Alfabeta. Bandung.

33. Suyanto, M (2009). Marketing Strategy for Top Brand Indonesia. Publisher, Andi Offset. Yogyakarta.

34. Suwondo (2011). Development of Public Administration Science in Government Bureaucracy. Publisher, Insan Cempaka. Surabaya.

35. Swastha, Basu and Irawan (2012). Marketing Management. Customer Satisfaction and Loyalty. Publisher, BPFE. Yogyakarta.

36. Zauhar, Soesilo (2009). Administrative Reform, Concepts, Dimensions and Strategies, Bumi Aksara, Jakarta. 
37. Zinkhan, and Donny, C (2017). Relationship between Corporate Image and Customer Loyalty. International Journal of Higher Education Management. 